УДК 338.45

DOI: https://doi.org/10.26642/jen-2019-3(89)-222-226

Л.П. Шаповал, к.е.н., доц. А.О. Булка, магістр

Кременчуцький національний університет імені Михайла Остроградського

\title{
Напрями збільшення доходів нафтопереробного підприсмства в умовах енергетичної залежності
}

\begin{abstract}
Стрімке поширення глобалізаційних процесів докорінно змінило принципи функціонування українських підприємств. Це пояснюється тим, щзо сьогодні глобалізаџія є умовою функціонування суб'єктів господарювання, а також визначає рівень конкурентоспроможності підприємств. У випадку нафтопереробного підприємства ПАТ «Укртатнафта» складні умови функціонування посилюються відсутністю державної підтримки підприємства як важливого об 'єкта створення та зберігання стратегічного запасу нафтопродуктів. Так негативний вплив справляють недосконала система державних закупівель нафтової сировини, несприятлива иінова кон'юнктура на вітчизняному ринку нафтопродуктів. Надаючи податкові преференції на постачання імпортних нафтопродуктів, уряд ставить вітчизняного виробника у невигідні умови. Це спровокувало пошук ПАТ «Укртатнафта» внутрішніх чинників забезпечення стабільності функціонування, зокрема, зростання доходів за рахунок проведення асортиментної та маркетингової політики. Проаналізовано склад, динаміку та структуру доходів ПАТ «Укртатнафта» за циих умов. Розглянуто основні заходи підвищення загального доходу від реалізації ПАТ «Укртатнафта»: покращення асортименту, зміна стратегії співпраці на ринку, удосконалення якості продукиії, розширення умов поставки нафтопродуктів. Наведене вище дозволило підприємству зберегти конкурентоспроможність, завершити реконструкиію багатьох установок, провести модернізацію та запропонувати новий енергетичний курс.

Ключові слова: доходи підприємства; дохід від реалізаџїі; інші операційні доходи; паливна промисловість; нафтопереробна галузь; нафтопродукти.
\end{abstract}

Актуальність теми. На сьогодні гостро стоїть питання здобуття енергетичної самостійності України [3], адже залежність вітчизняного ринку від постачання імпортних нафтопродуктів протягом останніх років сягала 50-80 \%. Водночас єдине наразі діюче нафтопереробне підприємство ПАТ «Укртатнафта» працює на мінімальному навантаженні (10,1-13,3 \% від виробничих потужностей). Це спричинено податковими преференціями, що діють в Україні на постачання імпортних нафтопродуктів. Така ситуація створює загрозу втрати не тільки конкурентоспроможності продукції вітчизняного виробника, а й стабільності паливного ринку та національним інтересам України. За таких умов важливого значення набувають внутрішні чинники збільшення доходів підприємства.

Аналіз останніх досліджень та публікації, на які спирається автор. Процесу формування доходів підприємства присвячено чимало публікацій, зокрема, таких авторів, як О.О. Кувалдіна [2], А.А. Попов [5], Н.Б. Фірко [8], О.В. Фоміна [9], Т.В. Черничко [10], В.І. Янчук [11] та ін. Однак, незважаючи на різноплановість робіт перерахованих фахівців, доцільно розглянути напрями зростання доходів ПАТ «Укртатнафта» в умовах енергетичної залежності, адже підприємство є єдиним джерелом виробництва вітчизняних нафтопродуктів європейської якості та має стратегічне значення для України.

Метою статті $\mathbf{\epsilon}$ виявлення напрямів збільшення доходів нафтопереробного підприємства ПАТ «Укртатнафта» в умовах критичного зростання обсягів імпортних нафтопродуктів на українському паливному ринку.

Викладення основного матеріалу. Формування доходів нафтопереробного підприємства має свою специфіку та відрізняється від загальної схеми формування доходів підприємства (рис. 1). Так загальний дохід ПАТ «Укртатнафта» становлять доходи від реалізації на внутрішньому та зовнішньому ринках, доходи від послуг щодо перероблення нафтової сировини, інші операційні доходи та отримані дивіденди.

Оскільки йдеться про підприємство промислового спрямування, дохід від реалізації продукції $є$ основою формування його доходів. Тому проведемо аналіз доходів від продажу нафтопродуктів у вартісних показниках на основі інформації про обсяги виробництва та реалізації основних видів продукції протягом 2015-2017 pp. [1].

Зазначимо, що у звітності ПАТ «Укртатнафта» відображаються лише основні види продукції, які становлять більше 5 \% від загального обсягу виробленої продукції в грошовому вимірі, решту нафтопродуктів (бітум, масло і масляні фракції, петролатум, сірка технічна та ін.) об'єднано у статтю «Інші нафтопродукти». Результати аналізу доходів від продажу основних видів нафтопродуктів відображено у таблиці 1.

(C) Л.П. Шаповал, А.О. Булка, 2019 


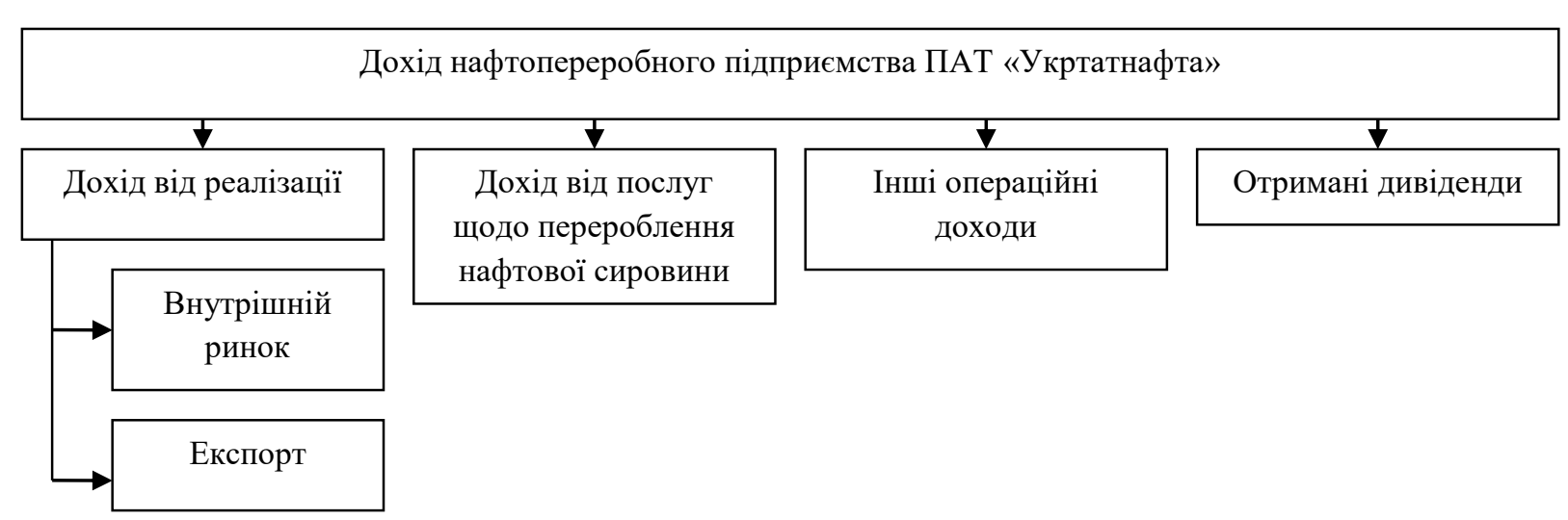

Рис. 1. Схема формування доходів нафтопереробного підприємства ПАТ «Укртатнафта»

Аналіз доходів від реалізачії основних видів нафтопродуктів

Таблиця 1 ПАТ «Укртатнафта» протягом 2015-2017 рр.

\begin{tabular}{|c|c|c|c|c|c|c|}
\hline \multirow{2}{*}{$\begin{array}{l}\text { № } \\
\text { 3/II }\end{array}$} & \multirow{2}{*}{ Найменування статті } & \multirow{2}{*}{$\begin{array}{l}2015 \text { p. } \\
\text { тис. грн }\end{array}$} & \multirow{2}{*}{\begin{tabular}{|l}
2016 p. \\
тис. грн
\end{tabular}} & \multirow{2}{*}{\begin{tabular}{|l}
2017 p. \\
тис. Грн
\end{tabular}} & \multicolumn{2}{|c|}{2017 p./2015 p. } \\
\hline & & & & & $-/+$ & $\%$ \\
\hline 1 & Бензин А-92 & 3663273,40 & 3970695,00 & 6296091,80 & 2632818,40 & 41,82 \\
\hline 2 & Бензин А-95 & 1930400,10 & 2987495,00 & 2851185,20 & 920785,10 & 32,29 \\
\hline 3 & Мазут 100 з.с. & 940076,40 & 1759659,70 & 2664061,30 & 1723984,90 & 64,71 \\
\hline 4 & Дизельне паливо, у т.ч.: & 3843305,90 & 3194483,30 & 7687664,50 & 3844358,60 & 50,01 \\
\hline 4.1 & (Свро) марки С вид II & 2001613,70 & 0,00 & 0,00 & $-2001613,70$ & - \\
\hline 4.2 & (Свро) марки F вид II & 1841692,20 & 0,00 & 0,00 & $-1841692,20$ & - \\
\hline 4.3 & Паливо диз. ДП-Л-Свро5-В0 & 0,00 & 3194483,30 & 4428354,70 & 4428354,70 & - \\
\hline 4.4 & $\begin{array}{c}\text { Паливо диз. ДП-Арк-Свро5- } \\
\text { В0 }\end{array}$ & 0,00 & 1570629.3 & 0,00 & 0,00 & - \\
\hline 4.5 & Паливо диз. ДП-3-Євро5-В0 & 0,00 & 0,00 & 3259309,80 & 3259309,80 & - \\
\hline 5 & Паливо РТ & 1645217,90 & 2105514,60 & 3119448,80 & 1474230,90 & 47,26 \\
\hline 6 & Інші нафтопродукти & 1440518,8 & 3703830,8 & 7300135,1 & 5859616,3 & 80,27 \\
\hline & Загальний обсяг & 13462792,50 & 17721678,40 & 29918586,70 & 10596177,90 & 55,00 \\
\hline
\end{tabular}

Протягом 2015-2017рр. асортимент реалізованих нафтопродуктів ПАТ «Укрататнафта» змінювався, оскільки підприємство постійно займалося удосконаленням якості продукції відповідно до міжнародних стандартів.

Так у 2016 р. на заміну дизельному паливу (Свро) марки C вид I та дизельному паливу (Свро) марки F вид I було введено нові нафтопродукти покращеної якості: дизельне паливо ДП-Л-Свро5-В0 (паливо літнє) та ДП-Арк-Свро5-В0 (паливо арктичне з температурою помутніння мінус 20). За рахунок того, що ця продукція відповідає стандарту Євро-5, вона стала унікальною в Україні.

У 2017 р. підприємство повністю перейшло на випуск бензину екологічного класу Свро-5 та при цьому продовжило випуск дизельного палива екологічного класу Євро-5 (літнього та зимового видів) [4].

Вдало проведена асортиментна політика дозволила збільшити загальний обсяг реалізованих нафтопродуктів у досліджуваному періоді на 55,00 \%. Зокрема, обсяги реалізованого бензину А-92 у 2017 р., порівняно із 2015 р. зросли на 41,82 \%, бензину А-95 - на 32,29 \%, мазуту - на 64,71 \%, усіх видів дизельного палива - на 50,01 \%, палива РТ - на 47,26 \%, інших нафтопродуктів - на 80,27 \%. Слід додати, що було проведено не лише удосконалення асортименту нафтопродуктів, а й покращення властивостей існуючих нафтопродуктів. Із метою створення унікальної на вітчизняному та зовнішньому ринках продукції та досягнення відповідності високим екологічним вимогам систематично проводився контроль за якістю продукції.

Проаналізуємо доходи від продажу основних видів нафтопродуктів у розрізі видів ринку внутрішнього та зовнішнього (експорт) (рис. 2). 


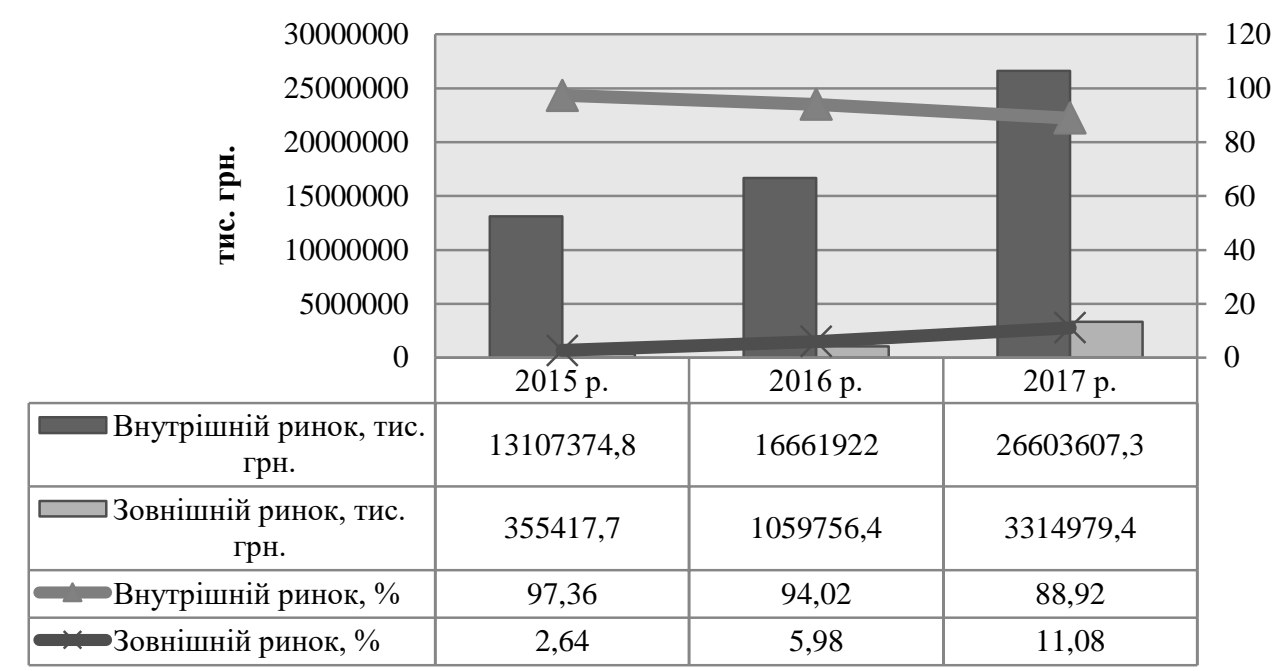

Рис. 2. Динаміка та структура доходів від реалізаиії нафтопродуктів ПАТ «Укртатнафта» на внутрішньому та зовнішньому ринках, 2015-2017 рр.

Отже, як видно з рисунка 2, основним ринком збуту для ПАТ «Укртатнафта» $є$ внутрішній. Покупцями на внутрішньому ринку є промислові підприємства, державні установи, авіаційні компанії, трейдери та власники АЗС.

Протягом 2015-2017 рр. сформувалася чітка тенденція до збільшення частки нафтопродуктів, вироблених на експорт (від 2,64 \% у 2015 р. до 11,08 \% у 2017 р.).

На зовнішній ринок ПАТ «Укртатнафта» реалізовує такі нафтопродукти: бензол нафтовий, рафінад бензольного риформінгу, мазут, паливо РТ. Основними імпортерами нафтопродуктів є авіаційні компанії та хімічні підприємства [7].

Слід зазначити, що протягом аналізованого періоду ПАТ «Укртатнафта» вдалося не тільки збільшити обсяги реалізації на вітчизняному та імпортному ринку, а й здійснити реконструкцію та модернізацію низки установок та обладнання [4].

Проаналізуємо динаміку обсягів виробництва нафтопродуктів у натуральних показниках протягом 2015-2017 рр. (табл. 2).

Аналіз динаміки обсягів виробниџтва основних видів нафтопродуктів

Таблиия 2 ПАТ «Укртатнафта», 2015-2017 рр.

\begin{tabular}{|c|c|c|c|c|c|c|}
\hline \multirow{2}{*}{$\begin{array}{l}\text { № } \\
\text { 3/II }\end{array}$} & \multirow{2}{*}{ Найменування статті } & \multirow{2}{*}{2015 p. } & \multirow{2}{*}{2016 p. } & \multirow{2}{*}{2017 p. } & \multicolumn{2}{|c|}{2017 p./2015 p. } \\
\hline & & & & & $-/+$ & $\%$ \\
\hline 1 & Бензин А-92 & 333857,28 & 318217,52 & 395354,77 & 61497,50 & 15,56 \\
\hline 2 & Бензин А-95 & 174376,27 & 254787,22 & 171944,92 & $-2431,35$ & $-1,41$ \\
\hline 3 & Мазут 100 3.с. & 265916,65 & 276049,86 & 338987,68 & 73071,03 & 21,56 \\
\hline 4 & Дизельне паливо, у т.ч.: & 516455,34 & 399169,62 & 557719,85 & 41264,51 & 7,40 \\
\hline 4.1 & (Свро) марки С вид II & 271420,71 & 0,00 & 0,00 & $-271420,71$ & - \\
\hline 4.2 & (Свро) марки F вид II & 245034,63 & 0,00 & 0,00 & $-245034,63$ & - \\
\hline 4.3 & Паливо диз. ДП-Л-Свро5-В0 & 0,00 & 276999,86 & 362192,36 & 362192,36 & - \\
\hline 4.4 & Паливо диз. ДП-Арк-Свро5-В0 & 0,00 & 122169,76 & 0,00 & 0,00 & - \\
\hline 4.5 & Паливо диз. ДП-3-Свро5-В0 & 0,00 & 0,00 & 195527,49 & 195527,49 & - \\
\hline 5 & Паливо РТ & 132829,88 & 163123,44 & 182729,11 & 49899,23 & 27,31 \\
\hline 6 & Інші нафтопродукти & 168774,22 & 326765,22 & 401443,19 & 232668,96 & 57,96 \\
\hline & Загальний обсяг & 1592209,64 & 1738112,88 & 2048179,52 & 455969,88 & 22,26 \\
\hline
\end{tabular}

Згідно з даними таблиці 2, за аналізований період загальний обсяг виробництва нафтопродуктів у натуральній формі зріс на 22,26 \%. Зокрема, найбільшою мірою протягом 2015-2017 pр. зріс обсяг виробництва інших нафтопродуктів (що складають до $5 \%$ у загальному обсязі виробництва) - на 57,96 \%.

У листопаді 2017 р. ПАТ «Укртатнафта» завершило реконструкцію та успішно запустило установку Г-24 в режимі гідроочищення фракції авіаційного палива для реактивних двигунів і очищення та деметалізації деасфальтизата - компонента сировини каталітичного крекінгу [4]. Це дозволило збільшити 
обсяги виробництва авіапалива РТ на 27,31 \%, порівняно із 2015 р., та підвищити гнучкість технологічної системи ПАТ «Укртатнафта». Оскільки цей вид палива відповідає сучасним стандартам і міжнародним нормам, на зовнішньому ринку протягом 2015-2017 рр. сформувався попит на таку продукцію.

У 2017 р. відбулися також важливі маркетингові нововведення - розширилися умови поставки авіапалива регіонами України: відвантаження залізничним транспортом, відвантаження автомобільним транспортом з Кременчука, заправка авіапалива в борт повітряного судна в аеропортах України.

Упродовж 2015-2017 pр. також збільшилися обсяги виробництва таких нафтопродуктів: мазуту (на $21,56 \%$ ), бензину А-92 (на 15,56 \%), дизельного палива (на 7,40 \%). Незначне зменшення обсягів виробництва відбулося лише за одним нафтопродуктом: бензином А-95 (на 1,41 \%).

Отже, попри складну економічну і політичну ситуацію в Україні, несприятливі умови для функціонування вітчизняної нафтопереробної галузі, ПАТ «Укртатнафта» протягом 2015-2017 рр. вдалося зберегти стабільність в роботі та збільшити обсяги виробництва нафтопродуктів.

Наступною складовою формування доходів компанії є інші операційні доходи (табл. 3).

Таблиияя 3

Аналіз динаміки інших операчійних доходів ПАТ «Укртатнафта», 2015-2017 рр., тис. грн

\begin{tabular}{|c|c|c|c|c|c|c|c|c|}
\hline \multirow{2}{*}{$\begin{array}{l}\text { № } \\
\text { 3/II }\end{array}$} & \multirow{2}{*}{ Назва статті } & \multirow{2}{*}{2015 p. } & \multirow{2}{*}{2016 p. } & \multicolumn{2}{|c|}{ Відхилення 2016/2015 } & \multirow{2}{*}{2017 p. } & \multicolumn{2}{|c|}{ Відхилення 2017/2015 } \\
\hline & & & & $+/-$ & $\%$ & & $+/-$ & $\%$ \\
\hline 1 & $\begin{array}{c}\text { Дохід від орендних } \\
\text { послуг }\end{array}$ & 481637 & 12849 & -468788 & $-3648,44$ & 5877 & -475760 & $-8095,29$ \\
\hline 2 & $\begin{array}{c}\text { Безповоротня } \\
\text { фінансова допомога }\end{array}$ & 0 & 0 & 0 & - & 261700 & 261700 & 100,00 \\
\hline 3 & $\begin{array}{l}\text { Дохід від торгівлі } \\
\text { іншими товарами } \\
\text { для перепродажу }\end{array}$ & 8372 & 12797 & 4425 & 34,58 & 28392 & 20020 & 70,51 \\
\hline 4 & $\begin{array}{c}\text { Прибуток за } \\
\text { пенсійним } \\
\text { зобов’язанням }\end{array}$ & 39806 & 4206 & -35600 & $-846,41$ & 0 & -39806 & - \\
\hline 5 & Інші доходи & 6841 & 41828 & 34987 & 83,64 & 27593 & 20752 & 75,21 \\
\hline & $\begin{array}{c}\text { Усього інших } \\
\text { операційних доходів }\end{array}$ & 536656 & 58831 & -477825 & $-812,20$ & 317685 & -218971 & $-68,93$ \\
\hline
\end{tabular}

Згідно з таблицею 3, загальна сума операційних доходів протягом періоду зменшилася на 68,93 \%. Більшою мірою цьому сприяло зменшення доходу від орендних послуг - від 481637 тис. грн у 2015 р. до 5877 тис. грн у 2017 р. Також суттєвою статтею інших операційних доходів у 2015 р. був прибуток за пенсійним зобов'язанням із встановленими виплатами внаслідок змін законодавства. У 2017 р. дохід за цією статтею був відсутній. Натомість протягом 2015-2017 pp. на 70,51 \% збільшилися доходи від торгівлі іншими товарами для перепродажу, на 75,21 \% зросли інші доходи. У 2017 р. ПАТ «Укртатнафта» була надана безповоротна фінансова допомога у розмірі 261700 тис. грн.

Також до джерел формування доходів належать отримані дивіденди, але протягом аналізованого періоду ПАТ «Укртатнафта» дивідендів не отримувало, тому це не вплинуло на зростання доходів підприємства.

Висновки та перспективи подальших досліджень. Таким чином, внаслідок розширення асортименту, удосконалення якості та систематичного контролю за продукцією, що випускається, ПАТ «Укртатнафта» вдалося суттєво збільшити обсяг виробництва нафтопродуктів та підвищити загальний дохід від реалізації. Це дозволило зберегти стабільність у роботі підприємства, завершити реконструкцію та модернізацію багатьох установок, підвищити рівень конкурентоспроможності продукції та сформувати попит на міжнародному ринку. ПАТ «Укртатнафта» може повністю забезпечити внутрішній ринок якісним паливом за відповідної підтримки держави та створити передумови для досягнення енергетичної незалежності України.

\section{Список використаної літератури:}

1. Булка А.О. Формування асортиментної політики ПАТ «Укртатанафта» / А.О. Булка // Авіація, промисловість, суспільство. - 2019. - С. 380-382.

2. Кувалдіна О.O. Методичне забезпечення аналізу доходів підприємства переробної промисловості / O.О. Кувалдіна [Електронний ресурс]. - Режим доступу : https://www.sworld.com.ua/konferm3/276.pdf.

3. Нова Енергетична стратегія України на період до 2035 року: «Безпека, енергоефективність, конкурентоспроможність» [Електронний ресурс]. http://mpe.kmu.gov.ua/minugol/doccatalog/document?id=245213112.

4. Офіційний сайт ПАТ «Укртатнафта» [Електронний ресурс] - Режим доступу : http://www.ukrtatnafta.com/archive.php?id=521. 
5. Попов А.А. Доходы предприятия в управленческом учете / A.А. Попов [Електронний ресурс]. - Режим доступу : http://www.elitarium.ru/dokhody_upravlencheskij_uchet.

6. Портер М. Конкуренция / М.Портер ; пер. с англ. - М. : ИД «Вильямс», 2000. - 496 с.

7. Публічне акціонерне товариство «Транснаціональна фінансово-промислова нафтова компанія «Укртатнафта» / Сміда [Електронний ресурс]. - Режим доступу: https://smida.gov.ua/db/participant/00152307.

8. Фірко Н.Б. Економічна суть та класифікація доходів підприємства: теоретичний аспект / Н.Б. Фірко [Електронний ресурс]. - Режим доступу : http://masters.donntu.org/2013/iem/tihonovskaya/library/article3.pdf.

9. Фоміна О.В. Управлінський облік доходів підприємств торгівлі: процесний підхід / О.В. Фоміна // Вісник ЖДТУ. - 2016. - № 3 (77). - С. 32-38.

10. Черничко T.B. Аналіз фінансових результатів діяльності підприємств України / T.B. Черничко, С.I. Кізман // Гроші, фінанси і кредит. - 2016. - № 5. - С. 400-404.

11. Янчук B.I. Особливості фінансового обліку та аналізу доходів і витрат в сільськогосподарських підприємствах / B.I. Янчук, I.C. Слободянюк // Збірник наукових праць ВНАУ. - 2012. - № 1 (56). - С. 123-130.

\section{References:}

1. Bulka, A.O. (2019), «Formuvannja asortymentnoi' polityky PAT «Ukrtatanafta», Aviacija, promyslovist', suspil'stvo, pp. 380-382.

2. Kuvaldina, O.O. (2016), «Metodychne zabezpechennja analizu dohodiv pidpryjemstva pererobnoi' promyslovosti», [Online], available at: https://www.sworld.com.ua/konferm3/276.pdf

3. Nova Energetychna strategija Ukrai'ny na period do 2035 roku: «Bezpeka, energoefektyvnist', konkurentospromozhnist'», [Online], available at: http://mpe.kmu.gov.ua/minugol/doccatalog/document?id=245213112

4. Oficijnyj sajt PAT «Ukrtatnafta», [Online], available at: http://www.ukrtatnafta.com/archive.php?id=521

5. Popov, A.A., Dokhody predpriyatiya $v$ upravlencheskom uchete, [Online], available at: http://www.elitarium.ru/dokhody_upravlencheskij_uchet

6. Porter, M. (2000), Konkurentsiya, ID «Vil'yams», Moscow, 496 p.

7. Smida, Publichne akcionerne tovarystvo «Transnacional'na finansovo-promyslova naftova kompanija «Ukrtatnafta», [Online], available at: https://smida.gov.ua/db/participant/00152307

8. Firko, N.B. (2011), Ekonomichna sut' ta klasyfikacija dohodiv pidpryjemstva: teoretychnyj aspect, [Online], available at: http://masters.donntu.org/2013/iem/tihonovskaya/library/article3.pdf

9. Fomina, O.V. (2016), «Management accounting of incomes of enterprises of trade: a process approach», Visnyk ZhDTU, Vol. 3 (77), pp. 32-38.

10. Chernychko, T.V. and Kizman, J.I. (2016), «Analysis of financial results of Ukrainian enterprises», Groshi, finansy $i$ kredyt, Vol. 5, pp. 400-404.

11. Janchuk, V.I. and Slobodjanjuk, I.S. (2012), «Features of financial accounting and analysis of income and expenditure in agricultural enterprises», Zbirnyk naukovyh prac' VNAU, Vol. 1 (56), pp. 123-130.

Шаповал Людмила Петрівна - кандидат економічних наук, доцент кафедри обліку і фінансів Кременчуцького національного університету імені Михайла Остроградського.

Наукові інтереси:

- дослідження проблем фінансової діяльності суб’єктів господарювання та фінансових посередників на грошовому ринку.

Булка Альона Олегівна - магістр кафедри обліку і фінансів Кременчуцького національного університету імені Михайла Остроградського.

Наукові інтереси:

- дослідження проблем фінансової діяльності суб’єктів господарювання та фінансових посередників на грошовому ринку.

E-mail: change.e@ukr.net. 